\title{
Development of a home literacy environment questionnaire for Tamil- speaking kindergarten children
}

\author{
B. Buvaneswari and Prakash Padakannaya *
} *Correspondence:
prakashp99@gmail.com
Department of Psychology,
University of Mysore, Mysore 570006, India

\begin{abstract}
Background: The development of emergent literacy skills depends upon the literacy environments and experiences of children at home. Children's home literacy environment is closely related to the development of various aspects of emergent literacy like letter knowledge, phonological awareness, and vocabulary. Dimensions of home literacy environment, such as physical (literacy) environment, child's own literacy habits, parental literacy habits, parent-child interaction for language and literacy activities, and parental beliefs about literacy, have been reported in literature.

Methods: The present study describes the construction of a home literacy environment questionnaire for Tamil-speaking kindergarten children in the Indian context. The various dimensions of home literacy environment were described, and items related to each dimension were listed. Seventeen judges rated each item on a five-point Likert scale ranging from 0 (no fit) to 4 (excellent fit). Their comments/ remarks/opinion, specific to an item or dimension, were also taken. The rating responses were analyzed for content validity and internal consistency.
\end{abstract}

Results: Content validity index was calculated at item level as well as scale level. The items in each subscale/dimension which had the item level content validity index scores higher than 0.78 were included in the final questionnaire and the other items were rejected. The scale level content validity index scores were higher than 0.90, indicating good content validity. Cronbach's alpha was calculated as a measure of internal consistency. Cronbach's alpha values were lower than 0.7 for three domains: physical environment, parent literacy habits, and parental beliefs.

Conclusions: The questionnaire developed promises to be a useful tool to evaluate the home literacy environment of Tamil children who undergo formal education in English medium schools like in India. The questionnaire developed and presented here can help in collecting reliable data to make informed decisions about children's (whether typically developing or with developmental disabilities) home literacy environment.

Keywords: Emergent literacy, Home literacy environment, Tamil-speaking children, Parent-child interaction, Parent literacy habits, Child literacy habits, Parental beliefs about literacy 


\section{Background}

Emergent literacy encompasses the variety of settings and experiences that support literacy and also helps in understanding the relationship between early literacy behaviors and conventional literacy. The term "emergent literacy" is used to denote the idea that the acquisition of literacy is best conceptualized as a developmental continuum, with its origins early in the life of a child, rather than an all-or-none phenomenon that begins when children start school (Whitehurst and Lonigan, 1998). The developmental and interactional relationship between the spoken and written forms of the language can be observed in emergent literacy skills (Goldsworthy, 2003).

Emergent literacy perspective has been borrowed from cognitive and social learning theories. According to Ferreiro (1986), emergent literacy emphasizes that children learn and discover literacy through their own attempts at reading and writing. This is in consonance with the Piagetian view that children are active participants in their own learning. According to the Piagetian view, the child is an active constructor of knowledge, capable of understanding and forming his own concepts about his environment. According to Vygotsky (1978), "learning awakens a variety of internal developmental processes that are able to operate only when the child is interacting with people in his environment and in cooperation with his peers." According to Rogoff (1990), the Vygotskian concept that young children learn from their interactions with others is applicable to emergent literacy skills. The development of literacy skills commences prior to formal academic instruction through experiences encountered in the home and may include games, songs, and even daily conversation (Landry and Smith, 2006).

The development of emergent literacy skills depends upon the literacy environments and experiences of children at home (Zucker and Grant, 2007) and school (Ezell and Justice, 2005). The home literacy environment is broadly defined as a multifarious interactive experience that occurs across multiple contexts and is frequently referred to as a key component in emergent literacy acquisition (Wood, 2002; Schmitt et al., 2011). Home literacy environment refers to the frequency and nature of literacy-related activities at home, most notably shared parent-child book reading. In addition, the age of onset of parent-child book reading, the number of books in the home, the frequency of trips to the library, and the frequency and enjoyment of reading by the primary caregiver is also considered aspects of the home literacy environment (Payne et al., 1994). The home environment typically provides the setting for emerging literacy knowledge by exposing children to various print forms and objects such as computer games, toys, television, board games, recipes, grocery lists, and reading materials which include newspapers, magazines, mail, and story books (McGinty and Justice, 2009). Home literacy environment helps in acquiring literacy knowledge, because it provides children with opportunities at home to observe the literacy activities of family members and also engage in joint reading and writing activities with others at home. Due to variations in the home literacy environment, children enter school with different levels of preparedness to benefit from the experiences at school (Whitehurst and Lonigan, 1998).

According to the study by Burgess, Hecht, and Lonigan (Burgess et al., 2002), there are different types of home literacy environment: (a) limiting home literacy environment, where the parents provide literacy opportunities to the children using resources that are at their disposal; (b) passive home literacy environment, where the parents provide a model to the children on literacy-related activities but do not involve themselves 
directly with the children for literacy activities; and (c) active home literacy environment, where the parents take efforts to directly engage in activities that help in literacy and language development in children.

Van Steensel (2006), from his study, describes three types of home literacy environments: (a) rich home literacy environment in which the parents and children participate in a variety of literacy activities; (b) child-directed home literacy environment, where there are less literacy activities, but important activities like shared reading, library visits, etc. are present; and (c) poor home literacy environment, where there is very little participation in literacy activities by either the parent or child. Home environments that offer a child ample opportunities to learn through interaction with adults and age-appropriate materials will lead to positive reading outcomes (Hart and Risley, 1992).

Apart from proximal factors of the child's home environment like family involvement, the effect of distal factors like socioeconomic status on the home literacy environment has also been discussed in the literature. Hart and Risley (2003) observed children from three socio-economic levels from infancy to age 3 and showed that children from low socioeconomic status families have significantly lesser listening/receptive vocabulary as compared to children from middle socioeconomic status families. The study by Van Kleeck (2004) discusses various strategies used by parents in the middle socioeconomic strata during language and literacy events at home-routine literacy-related activities such as storybook reading, encouraging more verbal interactions in the child during reading, understanding the child's present level of language and literacy skills, and providing new information accordingly. Rich language experiences during the preschool years help in better reading comprehension during the middle school (Snow and Dickinson, 1991). Through their analyses of homes and classrooms, Dickinson and Tabors (2001) identified three dimensions of children's experiences during the preschool and kindergarten years that were related to later literacy success: (a) exposure to varied vocabulary, (b) opportunities to be part of conversations that use extended discourse, and (c) home and classroom environments that are cognitively and linguistically stimulating.

Research on emergent literacy has supported the fact that there exists a strong relationship between children's home literacy environment and aspects of emergent literacy like letter knowledge, phonological awareness, and vocabulary (Rashid et al., 2005; Burgess et al., 2002; Frijters et al., 2000). There is a positive relationship between the frequency of home reading and children's vocabulary, letter-name knowledge, and phonological awareness. Thus, children's exposure to and experiences with print enhance language and emergent literacy skills (Sénéchal, 2006).

The following five dimensions of home literacy environment have been extensively reported in literature: (a) physical (literacy) environment (Curenton and Justice, 2008; Saracho, 1997; Niklas, 2015), (b) parent literacy habits (Nunley, 2000; Scarborough and Dobrich, 1994; Petrill et al., 2005), (c) child's own literacy habits (Deckner et al., 2006; Frijters et al., 2000; Justice et al., 2002), (d) parent-child interaction for language and literacy activities (Lehrl et al., 2012; Bingham, 2007; Clingenpeel and Pianta, 2007; Hood et al., 2008; Neumann et al., 2009), and (e) parental beliefs about literacy (Harkness and Super, 2006; Reese and Gallimore, 2000; Weigel et al., 2006a, 2006b).

Physical (literacy) environment is defined as the availability of literary resources and space at home (Curenton and Justice, 2008). Physical environments, such as homes, where books are accessible to children promote their perception of competence with 
print (Saracho, 1997). The role of physical (literacy) environment have been reported in the following studies: Niklas (2015) reported that the home literacy environment encompasses various literacy-related activities such as parental reading behavior, library visits, teaching of letters and sounds, and owning books at home. According to Niklas and Schneider (2013), aspects of home literacy environment such as parental reading, reading to the child, and the number of books in a household can predict children's emergent literacy skills such as vocabulary and phonological awareness. Rodriguez et al. (2009), from their study, concluded that it is important to have age-appropriate literacy materials at home as they are significant tools for facilitating children's engagement in literacy activities and parent-child interactions. The importance of having books and literacy-related materials at home, which are accessible to the child, has been discussed in various other studies (Weinberger, 1996; Weigel et al., 2006a, 2006b; Niklas, 2015; Park, 2008; Snow et al., 1998; Evans et al., 2000).

Parent literacy habits also have an effect on the literacy skills of children. The biggest influence on a child's reading is the parent's personal love for reading. A parent or caregiver who demonstrates the joy of reading has the biggest influence on a child's reading ability and lifelong interest in reading (Nunley, 2000). According to Scarborough and Dobrich (1994), parents who read frequently are also more likely to read to their children, and that this reading activity may be related to having more books available to themselves and their children in the home. A study by Petrill et al. (2005) concluded that the number of literacy materials in the home also may be mediated by the parents' educational level and intelligence. Studies by Christian et al., 1998), Gilger et al. (1991) and Heath (1982) also discuss the effects of maternal education and the parents' literacy abilities on the language and literacy development of children. Weigel et al. (2006a, 2006b), from their study, concluded that mothers of children with typical development, who have higher education levels, enjoy reading more, model writing to their children more often, read to their children more often, and more regularly engage in drawing pictures, singing songs, and telling stories with their children.

The child's own literacy habits also play a role in the development of emergent literacy skills. Deckner et al. (2006) operationally define child interest as the duration of engagement and participation by the child during shared interactions between the parent and the child. According to Justice et al. (2002), "literacy motivation describes children's interest in or orientation toward early literacy experiences." Thus, the child's own interest and motivation to participate in literacy-related activities is closely related to their emergent literacy skills. Studies by Durkin (1966) and Frijters et al. (2000) also support the view that children's own literacy habits contribute to their literacy accomplishments.

Parent-child interaction for language and literacy activities is defined as the activities intended to foster adult-child interactions that encourage children's active participation in reading, writing, and language activities, and in so doing, enhance their language and print literacy development (Jacobs, 2004). Lehrl et al. (2012) stated that the quality of parent-child interactions in a shared book reading situation helped in the growth of the children's vocabulary. Also, the quantity of book exposure helped in the growth of grammatical knowledge. Similar results were discussed in a study by Leseman and de Jong (1998). The fact that the quality of parent-child interactions during literacy activities remarkably helps in promoting the language and literacy development of children has been discussed in studies by Baker et al. (2001), Bingham (2007), Roberts et al. 
(2005), as well as Sonnenschein and Munsterman (2002). A variety of factors related to parent-child interaction like sensitivity of the parent toward the child (Clingenpeel and Pianta, 2007; de Jong and Leseman, 2001; Rabidoux and MacDonald, 2000; Whitehurst et al., 1988), how the parent teaches the child (Hood et al., 2008; Neumann et al., 2009; Sénéchal and LeFevre, 2002; Sénéchal et al., 1998), and whether the parent expresses positive regard toward the child (Dodici et al., 2003; Merlo et al., 2007) have been found to be related to children's development of early literacy skills.

Parental beliefs about literacy is an important dimension of home literacy environment. Parents' beliefs are components of a child's culturally structured "developmental niche" that inform parents' caregiving activities and practices (Harkness and Super, 2006). A study by Weigel et al. (2006a, 2006b) identified two profiles of parent (maternal) literacy beliefs: facilitative mothers who played an active role in teaching and reading to children and conventional mothers who believed that the school system, rather than the parents, are responsible for teaching their children. Another study by Bingham (2007) also found that maternal literacy beliefs are positively related to the home literacy environment, and in turn, the emergent literacy skills of children. Parental literacy beliefs are also related to children's emergent writing and receptive language (Weigel et al. 2006a, 2006b) and the child's motivation for reading (Baker and Scher, 2002). Studies by DeBaryshe et al. (2000), Teale (1986), and Reese and Gallimore (2000) also found relations between parental beliefs about literacy and children's emergent literacy skills. Thus, parents' beliefs and attitudes toward literacy, as well as their personal literacy practices, play very important roles in creating literacy-rich environments at home.

For children learning more than one language, the quality and quantity of language experiences in each language affect the development of emergent literacy skills (Hoff et al., 2012; Leseman et al., 2007). The purpose of this study was to develop a questionnaire to understand the home environments of children who learn Tamil as a home language from birth and English as a second language in school settings. The language and literacy environment or the home literacy environment in this study refers to the contexts in which a child directly or indirectly engages in and exposed to verbal and nonverbal behavior with his or her family members. The quality and quantity of exposure to each language varies for every child, leading to differences in the home literacy environment. Such variation in environments can affect the rate at which emergent literacy skills are learned in each language (Hoff and Core, 2013). The variation in home literacy environment depends on factors such as the proficiency of the family members in each language, involvement in literacy based activities at home, and cultural factors (Quiroz et al., 2010). All children in this study were exposed predominantly to Tamil at home and predominantly to English at school, although both the languages were used to varying extents in the both the contexts. Language- and literacy-related activities at home could include structured activities like book reading and word-learning games, as well as unstructured activities like meal time and television watching (Branum-Martin et al., 2014). Also, the amount of exposure to each language might be different across those activities. Structured activities like book reading may involve English more, while unstructured activities like meal times and television watching may involve Tamil. Many children, who learn English in formal settings, like in this study, come from cultures where storybook reading may not be a common practice (Edwards et al., 2009). However, the parents support cognitive growth through daily interactions, household responsibilities, and family activities (Thomas and Collier, 2012). 
Studies on the relations between home literacy environment factors and bilingual children's emergent literacy skills have been carried out in a socially superior language (Dixon, 2011; Kalia and Reese, 2009). Studies have also been carried out in mother tongue or ethnic language or non-dominant language of the society (Zhang and Koda, 2011). Some studies have been carried out in both languages (Duursma et al., 2007; Lu and Koda, 2011). Facilitative home literacy environments have been found to be helpful in the development of language and literacy skills in bilingual children. Through their study, Kalia and Reese (2009) found relationships between English exposure at home and receptive vocabulary and phonological awareness in English in Indian families. Also, parental book reading and teaching of print were related to the children's print knowledge in English. In a study by Duursma et al. (2007), it was found that by fifth grade, American Spanish speaking children's English proficiency did not depend on English language exposure and literacy support at home. But their proficiency in Spanish was related to both home literacy support and school instruction. Studies by Zhang and Koda (2011) as well as Lu and Koda (2011) suggest that good home literacy environments are important for children to learn and be proficient in the ethnic/non dominant language of the society. Although there have been studies on bilingual children's home literacy environment, there are very few studies about the bilingual home literacy environment in the Indian context, especially in Tamil-speaking children.

The Tamil language is very different from English. Tamil is primarily spoken in Tamil Nadu, a southeast state of India, and in the northern and eastern parts of Sri Lanka. Tamil is also spoken by migrant communities in countries like Malaysia, Singapore, Mauritius, Fiji, the United Kingdom, and the United States, among other countries. Tamil is diglossic (Ferguson, 1959), with a marked difference between the form that is used for writing and formal speaking and another form that is used for informal conversations.

In the western context, children are exposed to literate environments as young as infancy. They are socialized to understanding and relating to literature from a very young age (Heath, 1983). Emergent literacy behaviors such as gazing at pictures, turning pages of a book, scribbling and pretend reading are noticed very early in these children (Teale and Sulzby, 1986). Such a setting is uncommon in the Indian context, because oral traditions of storytelling are very strong in several regions of the country. This practice helps in fostering narrative skills and relate to literature pleasurably (retrieved from https:// www.careindia.org). There have been various home literacy questionnaires previously developed in the western context, but they have proved to have poor validity and reliability (Evans et al., 2000; Saracho, 2002). Although there are studies on the home literacy environments in the Indian context (Sharma and Saini, 2000; Khurana and Rao, 2008), there are no studies on the home literacy environment of Tamil-speaking children from middle socioeconomic status. Therefore, an attempt was made to develop a questionnaire to evaluate the home literacy environment of these children.

\section{Methods}

Based on the review of literature related to home literacy environment, 67 items were collected from the following questionnaires: (a) Family Literacy Environment Scale (Griffin and Morrison, 1997), (b) Home Literacy and Phonological Awareness (Foy and Mann, 2003), (c) Early Childhood Home Observation for the Measurement of Environment [HOME] Inventory (Caldwell and Bradley, 1984; 2003), (d) Home Literacy 
Environment Questionnaire (Martini, 2004), and (e) Ideas about Parenting Survey (Norman, 2007). The items were selected from these questionnaires based on their relevance to the five dimensions of home literacy environment (i.e., physical environment, parent literacy habits, child literacy habits, parent-child interaction for language and literacy activities, and parental beliefs about literacy). Out of the 67 items selected, 8 items each belonged to physical environment (PE), parent literacy habits (PLH), and child literacy habits (CLH) dimensions, while 31 items belonged to parent-child interaction (PCI) for language and literacy activities, and another 12 items represented parental beliefs $(\mathrm{PB})$ about literacy. The items in the questionnaire were randomized across dimensions, and a single list of items was prepared (Refer to Additional file 1).

A panel of 30 independent judges from the field of early intervention and early childhood education were selected to rate and judge whether the items adequately sample the domain of interest. The judges were speech-language pathologists, earlyintervention therapists, preschool teachers/principals and educators who were postgraduates in their respective subjects and had minimum 5 years of experience in working with preschool and kindergarten children. These judges were provided with the definitions of the five dimensions of home literacy as well as the instructions about how to rate each item for relevance to the specific domain (Refer to Additional file 2). The judges were asked to rate each item on a five-point Likert scale ranging from 0 (no fit) to 4 (excellent fit). If the judges felt that a particular item did not represent any dimension, they were asked to check under the column "non." A comment section was also provided to mark their comments/ remarks/ opinion, specific to an item or dimension. Example items were used to illustrate how rating should be performed. Detailed discussion was carried out with the judges to ensure that they understood the rating procedure. Out of the 30 judges, 17 returned the questionnaire after rating.

\section{Results and discussion}

The data collected from 17 judges were subjected to statistical analyses to establish content validity. Content validity has been defined as the degree to which an instrument has an appropriate sample of items for the construct being measured (Polit and Beck, 2004). Through content validity, we understand whether or not the items sampled for inclusion on the tool adequately represent the domain of content addressed by the instrument (Waltz et al., 2005). A widely reported method of content validity is "Content Validity Index (CVI)." Researchers compute two types of CVIs. The first type involves the content validity of individual items (ICVI), and the second involves the content validity of the overall scale (SCVI/Ave) (Lynn, 1986). Item level CVI (ICVI) refers to the percentage of experts who have rated the particular item as relevant with a score of 3 or more. According to Lynn (1986), when there are six or more judges, the ICVI scores should not be lower than 0.78. A score lower than 0.78 resulted in the omission of the item from the questionnaire.

Tables 1, 2, 3, 4 and 5 represent ICVI scores for the dimensions of PE, PLH, CLH, PCI, and PB, respectively. The ICVI scores for PE ranged from 0.88 to 1.00 (Table 1). Since all the items had an ICVI score higher than 0.78 , no item was rejected in the final questionnaire from this dimension. The ICVI scores for PLH (Table 2) ranged from 0.94 to 1.00 , and no item was rejected from this dimension. Table 3 represents the ICVI scores for CLH dimension. The ICVI scores ranged from 0.71 to 1.00 . Two items, 
Table 1 Item Level Content Validity Index (ICVI) for the dimension "Physical environment" (PE)

\begin{tabular}{llll}
\hline Item & Mean & ICVI & Interpretation \\
\hline My child has toys that teach colors, shapes sizes, etc. & 3.94 & 1.00 & Appropriate \\
My child has three or more puzzles & 3.76 & 0.94 & Appropriate \\
My child has toys or games requiring refined movements & 3.71 & 0.88 Appropriate \\
My child has at least 10 children's books & 3.65 & 0.88 Appropriate \\
My child has toys that help teach the names of animals, vehicles, fruits, etc. & 3.88 & 0.94 Appropriate \\
We have alphabet books/blocks/magnetic letters/flashcards/workbooks at home & 4.00 & 1.00 & Appropriate \\
There is a designated place for books and toys at home & 3.71 & 0.94 & Appropriate \\
The toys and books are accessible to the child & 4.00 & 1.00 & Appropriate \\
\hline
\end{tabular}

marked in bold, had an ICVI score lower than 0.78 and therefore were rejected. These items were not included in the final questionnaire. The ICVI scores for the PCI dimension showed that 8 out of the 31 items in the section were below 0.78 , and therefore those eight items were not included in the final questionnaire. Table 5 represents the ICVI scores for PE dimension. Two items, which had ICVI score below 0.78, were rejected from the final questionnaire.

Table 6 represents the Scale Level Content Validity Index SCVI/Ave scores for all the five dimensions. SCVI/Ave refers to the mean of ICVI for items whose ICVI $>0.78$. With respect to SCVI/Ave, a score of 0.90 or higher is acceptable (Davis, 1992; Grant and Davis, 1997; Polit and Beck, 2004). A score which is less than 0.9 indicates that the scale/subscale has poor content validity. All the SCVI/Ave scores were above 0.90, indicating that each of these dimensions has good content validity.

Cronbach's alpha, a measure of internal consistency (expressed as a number between 0 and 1) was then performed. It describes the extent to which all the items in a test measure the same concept or construct, and hence, it is connected to the interrelatedness of the items within the test (Tavakol and Dennick, 2011). Internal consistency reveals the extent to which items on a particular test are measuring the same attribute. Internal consistency can be measured through the split-half reliability index (Wong et al., 2012) and Cronbach's alpha (Cronbach, 1951). Out of all the internal consistency measures, Cronbach's alpha is the most widely used and is the most suitable (De Vaus, 2002) and provides the most thorough analysis of patterns of internal consistency. Alpha is preferable to the split-half method because it does not rely on just one split-half coefficient but on all the possible combinations of splits (De Vaus, 2002).

Table 2 Item Level Content Validity Index (ICVI) for the dimension "Parent literacy habits" (PLH)

\begin{tabular}{lll}
\hline Item & Mean ICVI Interpretation \\
\hline Our family buys and reads daily newspaper & 3.76 & 1.00 Appropriate \\
My child sees me writing/typing & 3.53 & 0.94 Appropriate \\
My child sees me reading non-work-related things, for pleasure & 3.71 & 0.94 Appropriate \\
My child sees me playing word games, crossword, etc. & 3.71 & 0.94 Appropriate \\
I enjoy talking about books related to various topics with friends and family & 3.71 & 1.00 Appropriate \\
members & 3.82 & 1.00 Appropriate \\
I go to bookstores/library along with my child & 3.94 & 1.00 Appropriate \\
I personally enjoy reading a habit & 3.88 & 0.94 Appropriate \\
My child sees me reading books/magazines/newspapers
\end{tabular}


Table 3 Item Level Content Validity Index (ICVI) for the dimension "Child literacy habits" (CLH)

\begin{tabular}{lll}
\hline Item & Mean ICVI Interpretation \\
\hline My child asks for help learning the letters of the alphabet & 3.71 & 1.00 Appropriate \\
My child asks for help while writing & 3.59 & 0.88 Appropriate \\
My child pretends to write by scribbling on paper & 3.41 & 0.76 Eliminated \\
My child asks for books to be read to him/her & 3.88 & 0.94 Appropriate \\
My child is interested in using computers, mobile phones, and other devices for & 2.76 & 0.71 Eliminated \\
learning & 3.65 & 0.94 Appropriate \\
My child pretends to read from books or says stories to himself/herself & 3.82 & 0.94 Appropriate \\
My child shows interest in reading signboards when we go out & 3.59 & 0.94 Appropriate \\
$\begin{array}{l}\text { My child shows interest in identifying the product by looking at an advertisement } \\
\text { or the wrapper of the product }\end{array}$ & & \\
\hline
\end{tabular}

Alpha is most appropriately used when the items measure different substantive areas within a single construct (Manerikar and Manerikar, 2015). In this study, home literacy environment is a single construct with five dimensions as the different substantive areas. According to Field (2009), if an instrument has subscales, then internal consistency measure should be applied separately to the subscales.

Table 7 shows the Cronbach's alpha values for the five dimensions. Cronbach's alpha values were lower than 0.7 for three domains: physical environment, parent literacy habits, and parental beliefs. This could mean that some of the items are not representatives of the dimensions. This could be due to the judges' perception of the interrelatedness of the dimensions. For example, some judges felt that parental belief is important in order to have an adequate physical (literacy) environment; parent literacy habit influences parent-child interaction for language and literacy activities. Therefore, the judges had difficulty in assigning a value of maximum fit to one specific dimension. This factor could have influenced the Cronbach's alpha values for internal consistency.

The judges were also given a scope of making remarks after the rating. The opinions/ remarks/suggestions of the judges were taken into consideration before finalizing the questionnaire. All the judges opined that the dimension "parent literacy habits" was closely linked to "parent-child interaction for language and literacy activities." Some judges felt that parental belief is important in order to have an adequate physical (literacy) environment and that this specific dimension (parental beliefs) influences all other dimensions. Therefore, they found it difficult to assign the value of maximum fit. All the judges agreed to the fact that parental beliefs play a major role in the development of emergent literacy skills in children.

Regarding "physical environment," some judges included environmental print as an aspect of the physical environment as well. They also remarked that physical environment should certainly include but not be limited just to books, puzzles, activity boards, toys, newspapers etc., but it should expand to accommodate any and all real world objects that can be used to associate and promote literacy skills. One judge was of the opinion that physical environment is not necessarily an important factor in the development of emergent literacy skills, because irrespective of the materials available, parental beliefs and parent-child interaction play a major role in determining the home literacy environment and the development of emergent literacy skills in children.

According to the judges, "parent literacy habits" define the child's long-term love for reading and writing. One of the judges assumes that parental literacy habits vary with 
Table 4 Item Level Content Validity Index (ICVI) for the dimension "Parent-child interaction for language and literacy activities" (PCl)

\begin{tabular}{|c|c|c|c|}
\hline Item & Mean & $|\mathrm{CV}|$ & Interpretation \\
\hline My child is encouraged to learn alphabets & 3.18 & 0.76 & Eliminated \\
\hline I teach simple verbal manners (please, sorry, thank you, etc. & 3.59 & 0.94 & Appropriate \\
\hline I encourage my child to talk and take time to listen & 3.35 & 0.82 & Appropriate \\
\hline I use big sentences and a variety of words to talk to my child & 3.24 & 0.76 & Eliminated \\
\hline I teach nursery rhymes and songs to my child & 3.94 & 1.00 & Appropriate \\
\hline I name pictures in books and talk about the pictures & 3.88 & 1.00 & Appropriate \\
\hline I read stories to my child & 3.82 & 1.00 & Appropriate \\
\hline I point out to words in magazines/newspapers & 3.88 & 1.00 & Appropriate \\
\hline I help my child solve jigsaw puzzles & 3.65 & 0.88 & Appropriate \\
\hline I encourage my child to draw pictures and copy and trace alphabets & 2.94 & 0.76 & Eliminated \\
\hline I give pencils/markers/crayons to my child to play with & 2.06 & 0.47 & Eliminated \\
\hline I encourage my child to act out a story & 3.12 & 0.82 & Appropriate \\
\hline I encourage my child to read product labels, street signs, and signboards & 3.53 & 0.94 & Appropriate \\
\hline When we read, I try to sound excited so my child stays interested & 3.88 & 1.00 & Appropriate \\
\hline I ask my child a lot of questions when we read & 3.82 & 1.00 & Appropriate \\
\hline I try to make the story more real to my child by relating the story to his/her life & 3.71 & 0.94 & Appropriate \\
\hline When we read, we talk about the pictures as much as we read the story & 3.94 & 1.00 & Appropriate \\
\hline When we read, I encourage my child to tell the story & 4.00 & 1.00 & Appropriate \\
\hline $\begin{array}{l}\text { When we read, I ask my child to point out to different letters/numbers printed in } \\
\text { the book }\end{array}$ & 3.82 & 0.94 & Appropriate \\
\hline I play reading-related games with my child & 3.76 & 1.00 & Appropriate \\
\hline I tell stories to my child & 3.94 & 1.00 & Appropriate \\
\hline I point my child's finger to words when I read to him/her & 3.71 & 1.00 & Appropriate \\
\hline I expand and complete my child's incomplete sentences when he/she speaks & 3.06 & 0.76 & Eliminated \\
\hline I ask for clarifications when I do not understand my child's speech & 3.18 & 0.76 & Eliminated \\
\hline I speak to my child about what happened during the day & 3.53 & 0.94 & Appropriate \\
\hline My child and I make new rhymes by playing with words/sounds & 3.88 & 1.00 & Appropriate \\
\hline I change my voice to suit the characters when I read to my child & 3.88 & 1.00 & Appropriate \\
\hline I talk to my child about what he/she watches on TV & 3.59 & 0.94 & Appropriate \\
\hline I use English to communicate with my child & 2.53 & 0.59 & Eliminated \\
\hline I use our home language to speak to my child & 3.29 & 0.76 & Eliminated \\
\hline $\begin{array}{l}\text { I translate the stories into our home language when my child does not } \\
\text { understand English words }\end{array}$ & 3.76 & 0.94 & Appropriate \\
\hline
\end{tabular}

the upbringing, socioeconomic status, personality, work-life balance, and other factors and that these factors should be analyzed to understand the home literacy environment. Most of the judges felt that since children learn through imitation, it is important for parents to model good literacy habits. Whereas, one judge felt that irrespective of the parents' literacy habits, if a child has interest in literacy and language, it contributes to the development of emergent literacy skills.

All the judges agreed that a child's own literacy habits contribute positively to the development of emergent literacy skills.

The dimension "parent-child interaction of language and literacy activities" was agreed to by all the judges as the major contributor to the home literacy environment. The judges 
Table 5 Item Level Content Validity Index (ICVI) for the dimension "Parental beliefs" (PB)

\begin{tabular}{|c|c|c|c|}
\hline Item & Mean & $\mathrm{ICVI}$ & Interpretation \\
\hline My child enjoys it when I teach him/her to read/write letters & 2.18 & 0.59 & Eliminated \\
\hline Parents can teach alphabets to their child in addition to what is taught in school & 3.71 & 0.94 & Appropriate \\
\hline $\begin{array}{l}\text { Parents can help their child to read and write words in addition to what is taught } \\
\text { in school }\end{array}$ & 3.59 & 0.94 & Appropriate \\
\hline $\begin{array}{l}\text { Most children do well at reading words in school because their parent teaches } \\
\text { them to read words at home }\end{array}$ & 3.65 & 1.00 & Appropriate \\
\hline Parents have the responsibility to teach reading and writing skills to their child & 3.94 & 1.00 & Appropriate \\
\hline $\begin{array}{l}\text { Most parents should supplement the literacy skills their child learns at school by } \\
\text { teaching their child literacy skills at home }\end{array}$ & 3.88 & 1.00 & Appropriate \\
\hline $\begin{array}{l}\text { Parents should select books based on their colorful illustrations high-interest con- } \\
\text { tent and natural language }\end{array}$ & 3.41 & 0.82 & Appropriate \\
\hline $\begin{array}{l}\text { Parents should develop the child's confidence and interest in putting ideas on } \\
\text { paper in whatever form they can (drawing writing etc.) }\end{array}$ & 3.76 & 0.94 & Appropriate \\
\hline $\begin{array}{l}\text { Parents should help in developing child's ability to divide a word into parts or } \\
\text { syllables to read new words }\end{array}$ & 3.65 & 0.94 & Appropriate \\
\hline When we read, I want my child to ask questions about the book & 2.47 & 0.53 & Eliminated \\
\hline I think that it is important to develop a broad interest in reading in my child & 4.00 & 1.00 & Appropriate \\
\hline $\begin{array}{l}\text { I think that it is important to develop my child's ability to hear the separate sounds } \\
\text { in spoken words such as "f" in "fish" or [p] in [padagu] in Tamil. }\end{array}$ & 3.65 & 0.94 & Appropriate \\
\hline
\end{tabular}

felt that such interaction is needed to enhance the child's interest in reading as well as improve his/her literacy skills. The judges also viewed parent-child interaction as the best way to establish a strong connection with their children. Some judges were of the opinion that educated parents provide an enriching learning environment, whereas some judges opined that even if a variety of books are not easily available to a child, if the parent spends time talking to them, singing songs, telling stories, making conversation, and encouraging the child to talk, it helps in creating a rich home literacy environment.

Regarding "parental beliefs" about literacy, the judges stated that parental belief is the root to all learning. The judges remarked that professionals in early education and intervention should first ascertain, acknowledge, and reassure parental beliefs while identifying and rectifying beliefs that may be detrimental to the development of literacy skills in the child. Parental beliefs can directly influence child's learning environment. The stronger the parental belief, the more likely is the parent going to be driven to interact with the child and encourage the learning experience.

Based on the statistical analysis, 8 items were selected from physical (literacy) environment, 8 items were selected from parent literacy habits, 6 items were selected from child literacy habits, 23 items were selected from parent-child interaction for language and literacy activities, and 10 items were selected from parental beliefs, to make a

Table 6 Scale Level Content Validity Index (SCVI/Ave) for the five dimensions

\begin{tabular}{lc}
\hline Dimension & SCVI / Ave \\
\hline Physical environment (PE) & 0.95 \\
Parent literacy habits (PLH) & 0.97 \\
Child literacy habits (CLH) & 0.94 \\
Parent-child interaction for language and literacy activities (PCl) & 0.96 \\
Parental beliefs (PB) & 0.95 \\
\hline
\end{tabular}


Table 7 Cronbach's alpha for the five dimensions

\begin{tabular}{llll}
\hline Dimension & $\begin{array}{l}\text { Cronbach's } \\
\text { alpha }\end{array}$ & $\begin{array}{l}\text { Cronbach's alpha Based on } \\
\text { standardized items }\end{array}$ & $\begin{array}{l}\text { No. of } \\
\text { items }\end{array}$ \\
\hline Physical environment & 0.656 & 0.660 & 6 \\
Parent literacy habits & 0.204 & 0.212 & 6 \\
Child literacy habits & 0.716 & 0.752 & 8 \\
Parent- child interaction for language and & 0.825 & 0.847 & 29 \\
literacy activities & & & 11 \\
Parental beliefs & 0.516 & 0.633 & 11 \\
\hline
\end{tabular}

questionnaire containing 55 items (Refer to Additional file 3). However, we acknowledge the limitation that the sample size of experts we had was small for the analyses.

\section{Conclusions}

The present study was an attempt to develop a questionnaire for understanding the home literacy environment of Tamil-speaking children from middle socioeconomic status. For this purpose, items from various home literacy environment questionnaires were collected and 67 items from five dimensions (physical environment, parent literacy habits, child literacy habits, parent-child interaction for language, and literacy activities and parental beliefs). Seventeen judges rated each of these items on a five-point Likert scale ranging from 0 (no fit) to 4 (excellent fit). A comment section was also provided to mark their comments/remarks/opinion, specific to an item or dimension. The responses of the judges were subjected to quantitative and qualitative analyses to arrive at a final list of items for the questionnaire.

Based on the statistical analysis (Content Validity Index), a total of 12 items were eliminated and the final questionnaire was constructed using 55 items. The qualitative analyses revealed that the judges had difficulty in deciding on the specific items that would best represent each dimension, as some of the items in the questionnaire were overlapping across dimensions. The questionnaire developed promises to be a useful tool to evaluate the home literacy environment of Tamil children who undergo formal education in English medium schools like in India. Parents play an important role in children's literacy development. It is important to have an understanding of the various dimensions of home literacy environment and the specific elements of these dimensions for assessing the development of emergent literacy skills in children. The questionnaire developed through this study can help in collecting reliable data to make informed decisions about children's (whether typically developing or with developmental disabilities) home literacy environment.

\section{Additional files}

Additional file 1: Home literacy environment initial item pool. (DOCX $30 \mathrm{~kb}$ )

Additional file 2: Instructions and operational definitions of the home literacy environment dimensions. (DOCX $11 \mathrm{~kb})$

Additional file 3: Home literacy environment questionnaire. (DOCX $22 \mathrm{~kb}$ ) 


\section{Competing interests}

The authors declare that they have no competing interests.

\section{Publisher's Note}

Springer Nature remains neutral with regard to jurisdictional claims in published maps and institutional affiliations.

Received: 10 July 2017 Accepted: 12 September 2017

Published online: 03 November 2017

\section{References}

Baker, L., Mackler, K., Sonnenschein, S., \& Serpell, R. (2001). Parents' interactions with their first-grade children during storybook reading and relations with subsequent home reading activity and reading achievement. Journal of School Psychology, 39(5), 415-438.

Baker, L., \& Scher, D. (2002). Beginning readers' motivation for reading in relation to parental beliefs and home reading experiences. Reading Psychology, 23(4), 239-269.

Bingham, G. E. (2007). Maternal literacy beliefs and the quality of mother-child book-reading interactions: assoications with children's early literacy development. Early Education and Development, 18(1), 23-49.

Branum-Martin, L., Mehta, P. D., Carlson, C. D., Francis, D. J., \& Goldenberg, C. (2014). The nature of Spanish versus English language use at home. Journal of Educational Psychology, 106(1), 181.

Burgess, S. R., Hecht, S. A., \& Lonigan, C. J. (2002). Relations of the home literacy environment (HLE) to the development of reading-related abilities: a one-year longitudinal study. Reading Research Quarterly, 37(4), 408-426.

Caldwell, B. M., \& Bradley, R. H. (1984). Home observation for measurement of the environment. Little Rock: University of Arkansas at Little Rock.

Caldwell, B. M., \& Bradley, R. H. (2003). Home observation for measurement of the environment: administration manual. Tempe, AZ: Family \& Human Dynamics Research Institute, Arizona State University.

Christian, K., Morrison, F. J., \& Bryant, F. B. (1998). Predicting kindergarten academic skills: interactions among child care, maternal education, and family literacy environments. Early Childhood Research Quarterly, 13(3), 501-521.

Clingenpeel, B. T., \& Pianta, R. C. (2007). Mothers' sensitivity and book-reading interactions with first graders. Early Education and Development, 18(1), 1-22

Cronbach, L. J. (1951). Coefficient alpha and the internal structure of tests. Psychometrika, 16(3), 297-334.

Curenton, S. M., \& Justice, L. M. (2008). Children's preliteracy skills: influence of mothers' education and beliefs about shared-reading interactions. Early Education and Development, 19(2), 261-283.

Davis, L. L. (1992). Instrument review: getting the most from a panel of experts. Applied Nursing Research, 5(4), 194-197.

De Jong, P. F., \& Leseman, P. P. (2001). Lasting effects of home literacy on reading achievement in school. Journal of School Psychology, 39(5), 389-414.

De Vaus, D. (2002). Analyzing social science data: 50 key problems in data analysis. SAGE Publications.

DeBaryshe, B. D., Binder, J. C., \& Buell, M. J. (2000). Mothers' implicit theories of early literacy instruction: implications for children's reading and writing. Early Child Development and Care, 160(1), 119-131.

Deckner, D. F., Adamson, L. B., \& Bakeman, R. (2006). Child and maternal contributions to shared reading: effects on language and literacy development. Journal of Applied Developmental Psychology, 27(1), 31-41.

Dickinson, D. K., \& Tabors, P. O. (2001). Beginning literacy with language: Young children learning at home and school. Baltimore: Paul H Brookes Publishing.

Dixon, L. Q. (2011). The role of home and school factors in predicting English vocabulary among bilingual kindergarten children in Singapore. Applied PsychoLinguistics, 32(1), 141-168.

Dodici, B. J., Draper, D. C., \& Peterson, C. A. (2003). Early parent-child interactions and early literacy development. Topics in Early Childhood Special Education, 23(3), 124-136.

Durkin, D. (1966). Children who read early. New York: Teachers College Press, Columbia University.

Duursma, E., Romero-Contreras, S., Szuber, A., Proctor, P., Snow, C., August, D., \& Calderón, M. (2007). The role of home literacy and language environment on bilinguals' English and Spanish vocabulary development. Applied PsychoLinguistics, 28(1), 171-190.

Edwards, P., Paratore, J., \& Roser, N. (2009). Family literacy: recognizing cultural significance. In L. Morrow, R. Rueda, \& D. Lapp (Eds.), Handbook on research on literacy instruction (pp. 77-96). New York: Guilford Press.

Evans, M. A., Shaw, D., \& Bell, M. (2000). Home literacy activities and their influence on early literacy skills. Canadian Journal of Experimental Psychology, 54(2), 65.

Ezell, H. K., \& Justice, L. M. (2005). Shared storybook reading: building young children's language and emergent literacy skills. Baltimore: Paul H. Brookes Publishing Co..

Ferguson, C. (1959). Diglossia. Word, 15, 325-340.

Ferreiro, E. (1986). The interplay between information and assimilation in beginning literacy. In W. H. Teale \& E. Sulzby (Eds.), Emergent literacy: Writing and reading, 15-49.

Field, A. (2009). Discovering statistics using SPSS. New Delhi: Sage Publications.

Foy, J. G., \& Mann, V. (2003). Home literacy environment and phonological awareness in preschool children: differential effects for rhyme and phoneme awareness. Applied PsychoLinguistics, 24(1), 59-88.

Frijters, J. C., Barron, R. W., \& Brunello, M. (2000). Direct and mediated influences of home literacy and literacy interest on prereaders' oral vocabulary and early written language skill. Journal of Educational Psychology, 92(3), 466.

Gilger, J. W., Pennington, B. F., \& Defries, J. C. (1991). Risk for reading disability as a function of parental history in three family studies. Reading and Writing, 3(3-4), 205-217.

Goldsworthy, C. L. (2003). Developmental reading disabilities: a language based treatment approach (2nd ed.). Clifton Park: Thomson/Delmar Learning.

Grant, J. S., \& Davis, L. L. (1997). Selection and use of content experts for instrument development. Research in Nursing \& Health, 20(3), 269-274. 
Griffin, E. A., \& Morrison, F. J. (1997). The unique contribution of home literacy environment to differences in early literacy skills. Early Child Development and Care, 127(1), 233-243.

Harkness, S., \& Super, C. M. (2006). Themes and variations: parental ethnotheories in Western cultures. In K. H. Rubin \& O. B. Chung (Eds.), Parenting beliefs, behaviors, and parent child relations: A cross-cultural perspectives (pp. 61-79). New York: Psychology Press.

Hart, B., \& Risley, T. R. (1992). American parenting of language-learning children: persisting differences in family-child interactions observed in natural home environments. Developmental Psychology, 28(6), 1096.

Hart, B., \& Risley, T. R. (2003). The early catastrophe: the 30 million word gap by age 3. American Educator, 27(1), 4-9.

Heath, S. B. (1983). Ways with words: language, life, and work in communities and classrooms. Cambridge: Cambridge University Press.

Hoff, E., \& Core, C. (2013). Input and language development in bilingually developing children. Seminars in Speech and Language, 34(4), 215-226.

Hoff, E., Core, C., Place, S., Rumiche, R., Señor, M., \& Parra, M. (2012). Dual language exposure and early bilingual development. Journal of Child Language, 39(1), 1-27.

Hood, M., Conlon, E., \& Andrews, G. (2008). Preschool home literacy practices and children's literacy development: a longitudinal analysis. Journal of Educational Psychology, 100(2), 252.

Jacobs, K. (2004). Parent and child together time. In B. H. Wasik (Ed.), Handbook of family literacy (pp. 193-213). New Jersey: Lawrence Erlbaum.

Justice, L. M., Weber, S. E., Ezell, H. K., \& Bakeman, R. (2002). A sequential analysis of children's responsiveness to parental print references during shared book-reading interactions. American Journal of Speech-Language Pathology, 11(1), 30-40.

Kalia, V., \& Reese, E. (2009). Relations between Indian children's home literacy environment and their English oral language and literacy skills. Scientific Studies of Reading, 13(2), 122-145.

Khurana, S., \& Rao, P. K. (2008). Emergent literacy experiences at home-a sample survey in Mysore City. Language in India, 8(8), 1-18.

Landry, S. H., \& Smith, K. E. (2006). The influence of parenting on emerging literacy skills. In D. Dickinson \& S. Neuman (Eds.), Handbook of Early Literacy Research (Vol 2.) (pp. 135-148). New York: Gilford Press.

Lehrl, S., Ebert, S., Rossbach, H. G., \& Weinert, S. (2012). Effects of the home learning environment on children's emerging literacy. Zeitschrift Fur Familienforschung, 24(2), 115-133.

Leseman, P. P., \& Jong, P. F. (1998). Home literacy: opportunity, instruction, cooperation and social-emotional quality predicting early reading achievement. Reading Research Quarterly, 33(3), 294-318.

Leseman, P. P., Scheele, A. F., Mayo, A. Y., \& Messer, M. H. (2007). Home literacy as a special language environment to prepare children for school. Zeitschrift für Erziehungswissenschaft, 10(3), 334-355.

Lu, C., \& Koda, K. (2011). Impact of home language and literacy support on English-Chinese biliteracy acquisition among Chinese heritage language learners. Heritage Language Journal, 8(2), 44-80.

Lynn, M. R. (1986). Determination and quantification of content validity. Nursing Research, 35(6), 382-386.

Manerikar, V., \& Manerikar, S. (2015). Cronbach's alpha. A Peer review research journal. aWEshkar WeSchool, 19(1), 117-119.

Martini, F. (2004). The role of parents in their child's acquisition of early literacy skills. Unpublished masters dissertation. Carleton University, Canada.

McGinty, A. S., \& Justice, L. M. (2009). Predictors of print knowledge in children with specific language impairment: experiential and developmental factors. Journal of Speech, Language, and Hearing Research, 52(1), 81-97.

Merlo, L. J., Bowman, M., \& Barnett, D. (2007). Parental nurturance promotes reading acquisition in low socioeconomic status children. Early Education and Development, 18(1), 51-69.

Neumann, M. M., Hood, M., \& Neumann, D. L. (2009). The scaffolding of emergent literacy skills in the home environment: a case study. Early Childhood Education Journal, 36(4), 313-319.

Niklas, F. (2015). The learning environment provided by the family and its impact on the development of child competencies. Psychologie in Erziehung und Unterricht, 62(2), 106-120.

Niklas, F., \& Schneider, W. (2013). Home literacy environment and the beginning of reading and spelling. Contemporary Educational Psychology, 38(1), 40-50.

Norman, RC. (2007). Do Parents' literacy beliefs and home literacy experiences relate to children's literacy skills? Unpublished masters dissertation. Brigham Young University.

Nunley, K. (2000). The layered curriculum. New York: Harcourt-Brace.

Park, B. (2008). The earlier, the better: early intervention programs for infants and toddlers at risk. Dimensions of Early Childhood, 36(1), 3

Payne, A. C., Whitehurst, G. J., \& Angell, A. L. (1994). The role of home literacy environment in the development of language ability in preschool children from low-income families. Early Childhood Research Quarterly, 9(3-4), 427-440.

Petrill, S. A., Deater-Deckard, K., Schatschneider, C., \& Davis, C. (2005). Measured environmental influences on early reading: evidence from an adoption study. Scientific Studies of Reading, 9(3), 237-259.

Polit, D. F., \& Beck, C. T. (2004). Nursing research: principles and methods (7th ed.). Philadelphia: Lippincott.

Quiroz, B. G., Snow, C. E., \& Zhao, J. (2010). Vocabulary skills of Spanish—English bilinguals: impact of mother—child language interactions and home language and literacy support. International Journal of Bilingualism, 14(4), 379-399.

Rabidoux, P. C., \& MacDonald, J. D. (2000). An interactive taxonomy of mothers and children during storybook interactions. American Journal of Speech-Language Pathology, 9(4), 331-344.

Rashid, F. L., Morris, R. D., \& Sevcik, R. A. (2005). Relationship between home literacy environment and reading achievement in children with reading disabilities. Journal of Learning Disabilities, 38(1), 2-11.

Reese, L., \& Gallimore, R. (2000). Immigrant Latinos' cultural model of literacy development: an evolving perspective on home-school discontinuities. American Journal of Education, 108(2), 103-134.

Roberts, J., Jergens, J., \& Burchinal, M. (2005). The role of home literacy practices in preschool children's language and emergent literacy skills. Journal of Speech, Lanquage, and Hearing Research, 48(2), 345-359.

Rodriguez, E. T., Tamis-LeMonda, C. S., Spellmann, M. E., Pan, B. A., Raikes, H., Lugo-Gil, J., \& Luze, G. (2009). The formative role of home literacy experiences across the first three years of life in children from low-income families. Journal of Applied Developmental Psychology, 30(6), 677-694. 
Rogoff, B. (1990). Apprenticeship in thinking. Cognitive development in social context. New York: Oxford University Press Saracho, O. N. (1997). Using the home environment to support emergent literacy*. Early Child Development and Care, $127(1), 201-216$

Saracho, O. N. (2002). Family literacy: exploring family practices. Early Child Development and Care, 172(2), 113-122.

Scarborough, H. S., \& Dobrich, W. (1994). On the efficacy of reading to preschoolers. Developmental Review, 14(3), 245-302.

Schmitt, S. A., Simpson, A. M., \& Friend, M. (2011). A longitudinal assessment of the home literacy environment and early language. Infant and Child Development, 20(6), 409-431.

Sénéchal, M. (2006). Testing the home literacy model: parent involvement in kindergarten is differentially related to grade 4 reading comprehension, fluency, spelling, and reading for pleasure. Scientific Studies of Reading, 10(1), 59-87.

Sénéchal, M., \& LeFevre, J. A. (2002). Parental involvement in the development of children's reading skill: a five-year longitudinal study. Child Development, 73(2), 445-460.

Sénéchal, M., Lefevre, J. A., Thomas, E. M., \& Daley, K. E. (1998). Differential effects of home literacy experiences on the development of oral and written language. Reading Research Quarterly, 33(1), 96-116.

Sharma, S., \& Saini, S. (2000). Influence of social stratification, occupation and income of the parents on the home environment of pre-schoolers. Asian Journal of Psychology and Education, 33(5/6), 11-17.

Snow, C., Burns, M., \& Griffin, P. (Eds.). (1998). Preventing reading difficulties in young children. Washington DC: National Academy Press.

Snow, C. E., \& Dickinson, D. K. (1991). Skills that aren't basic in a new conception of literacy. In A. Purves \& E. Jennings (Eds.), Literate systems and individual lives: Perspectives on literacy and schooling. Albany: SUNY Press.

Sonnenschein, S., \& Munsterman, K. (2002). The influence of home-based reading interactions on 5-year-olds' reading motivations and early literacy development. Early Childhood Research Quarterly, 17(3), 318-337.

Tavakol, M., \& Dennick, R. (2011). Making sense of Cronbach's alpha. International Journal of Medical Education, 2, 53.

Teale, W. H. (1986). Home background and young children's literacy development. In W. H. Teale \& E. Sulzby (Eds.), Emergent literacy: Writing and reading (pp. 173-206). Norwood: Ablex Publishing Corporation.

Teale, W. H., \& Sulzby, E. (1986). Emergent literacy: writing and reading. Writing research: multidisciplinary inquiries into the nature of writing series. Norwood: Ablex Publishing Corporation

Thomas, W. P., \& Collier, V. P. (2012). Dual language education for a transformed world. Albuquerque: Fuente Press.

van Kleeck, A. (2004). Fostering preliteracy development via storybooksharing interactions: the cultural context of mainstream family practices. In C. A. Stone, E. R. Silliman, B. Ehren, \& K. Apel (Eds.), Handbook of language and literacy: Development and disorders (pp. 175-208). New York: The Guilford Press.

Van Steensel, R. (2006). Relations between socio-cultural factors, the home literacy environment and children's literacy development in the first years of primary education. Journal of Research in Reading, 29(4), 367-382.

Vygotsky, L. S. (1978). Mind in society: the development of higher psychological processes. Cambridge: Harvard University Press.

Waltz, C. F., Strickland, O. L., \& Lenz, E. (2005). Measurement in nursing and health research (3rd ed.). New York: Springer Publishing Company.

Weigel, D. J., Martin, S. S., \& Bennett, K. K. (2006a). Contributions of the home literacy environment to preschool-aged children's emerging literacy and language skills. Early Child Development and Care, 176(3-4), 357-378.

Weigel, D. J., Martin, S. S., \& Bennett, K. K. (2006b). Mothers' literacy beliefs: connections with the home literacy environment and pre-school children's literacy development. Journal of Early Childhood Literacy, 6(2), 191-211.

Weinberger, J. (1996). A longitudinal study of children's early literacy experiences at home and later literacy development at home and school. Journal of Research in Reading, 19(1), 14-24.

Whitehurst, G. J., Falco, F. L., Lonigan, C. J., Fischel, J. E., DeBaryshe, B. D., Valdez-Menchaca, M. C., \& Caulfield, M. (1988). Accelerating language development through picture book reading. Developmental Psychology, $24(4), 552$.

Whitehurst, G. J., \& Lonigan, C. J. (1998). Child development and emergent literacy. Child Development, 69(3), 848-872

Wong, K. L., Ong, S. F., \& Kuek, T. Y. (2012). Constructing a survey questionnaire to collect data on service quality of business academics. European Journal of Social Sciences, 29, 209-221.

Wood, C. (2002). Parent-child pre-school activities can affect the development of literacy skills. Journal of Research in Reading, 25(3), 241-258.

Zhang, D., \& Koda, K. (2011). Home literacy environment and word knowledge development: a study of young learners of Chinese as a heritage language. Bilingual Research Journal, 34(1), 4-18.

Zucker, T. A., \& Grant, S. L. (2007). Assessing home supports for literacy. In K. L. Pence (Ed.), Assessment in emergent literacy (pp. 81-187). San Diego: Plural Publishing.

\section{Submit your manuscript to a SpringerOpen ${ }^{\circ}$ journal and benefit from:}

- Convenient online submission

Rigorous peer review

Open access: articles freely available online

- High visibility within the field

- Retaining the copyright to your article

Submit your next manuscript at $\gg$ springeropen.com 